\title{
A Conceptual Framework to Measure Customer Experience towards Organic Food Products in India
}

\author{
Ratna Banerjee \\ School of Business, University of Petroleum and \\ Energy Studies Dehradun, India
}

\author{
Remica Aggarwal \\ MIT-SOER, MIT-ADT University, Loni Kalabhor, \\ Pune, India
}

\begin{abstract}
Today's customers are smart and educated and are more aware of the benefits and goodness of healthy as well as environment friendly food products. They motivate the manufacturers to bring innovative products in market or to redesign the existing products to meet their needs and simultaneously conforming to the environmental standards. Organic foods are one such class of sustainable food products which have been overwhelmingly realized in India as well. As consumers are becoming more health conscious, it is of curiosity to analyze what motivates them to buy these sustainable or organic food products. Exhaustive literature review provides various criteria or governing factors that in turn governs the attitude of consumers towards product purchase. This study aims to present a conceptual framework using these factors and construction of hypotheses to study the perception, awareness, knowledge and behaviour of consumers towards organic food products in India.
\end{abstract}

\section{Keywords}

Organic food products, sustainable food products, sustainability, agribusiness, consumer behaviour

\section{INTRODUCTION}

The growing awareness regarding environmental sustainability is making the consumers as well as companies to look for alternatives to mitigate the pressing environmental demands due to rise in population and country's economic growth. With India's economy powers on and rise in income levels, there will be an increasing demand for more and better food. Add on it the urbanization and rise in education levels of consumers. Customers look for healthy as well as environmental friendly consumer products. This also serve as opportunity for those manufacturers who believe in innovation and redesigning products and services in ecological manner. Organic food products are such a class of sustainable products, which are cultivated using bio composites, or fertilizers that are environment friendly and biodegradable. Sustainable management of organic food products will reduce environmental degradation as well as will lead to increased employment opportunities for farmers as well as logistics service providers. Also, production and consumption of sustainable products goes hand in hand as with increase in consumption motivates production and thereby increasing the need for training farmers to grow organic food. As consumers are becoming more health conscious, it is of curiosity to analyze what motivates them to buy these sustainable or organic food products. Exhaustive literature review provides various criteria or governing factors that in turn governs the attitude of consumers towards product purchase. This study aims to present a conceptual framework using these factors and construction of hypotheses to study the perception, awareness, knowledge and behavior of consumers towards organic food products in India. Therefore, the primary objectives of the present study are as follows:
- To identify the various criteria and sub criteria affecting the attitude of consumers towards organic food products

- To construct a conceptual framework to link the criteria and sub criteria

- To construct hypotheses based on the conceptual framework

The paper is organized as follows: section 2 presents the literature review and identification of various factors based on review of literature. Section 3 presents the conceptual framework. Section 4 presents the various hypotheses. Section 5 presents the conclusion and managerial implications of the research.

\section{LITERATURE REVIEW}

Many developed countries in the west have already marked considerable efforts in thearea of organic farming while it is still in the nascent stage in most third world countries [1]. Despite of the inherent problems attributed to various socio-economic factors, production of sustainable products is full of new opportunities for companies. There are available researches considering sustainable products mainly with the aim of targeting related customers [2]. Organic products such as organic foods are produced with no chemical material to maximize sustainability [3]. Moreover, there are changes in consumer behaviors towards organic food consumption as they believed by consuming these products, they can protect environment [4], and consumers are willing to pay more for these products due to health issue and protecting environment [5].

Benefits of organic foods have been overwhelmingly realized in India as well. Ten most brought organic food products are mentioned in the table 1 given below. Popular brands like Amira, Patanjali, Organic India, Green Sense, Genera etc. are actively promoting organic food products in India. Also in the era of digitizing India, these organic food products could be brought through online stores such as Amazon, Fab India, big basket, India mart, Nature basket etc. 


\begin{tabular}{|c|c|c|}
\hline S. No. & Category -Examples & How they are cultivated and their nutritional values \\
\hline 1. & $\begin{array}{l}\text { Organic vegetables: } \\
\text { Spinach, Tomatoes, Cauliflower, } \\
\text { Potato, Bitter gourd, Carrot, } \\
\text { Capsicum, Green chili, Brinjal }\end{array}$ & $\begin{array}{l}\text { Organic produce mostly has the exposure of humans } \\
\text { rather than the toxic chemicals and fertilizers. }\end{array}$ \\
\hline 2. & $\begin{array}{l}\text { Organic fruits: } \\
\text { Alphonso Mangoes, Pomegranates, } \\
\text { Bananas, Peaches, Apples }\end{array}$ & $\begin{array}{l}\text { No shots of ethylene hormones and quick ripening } \\
\text { chemicals like acetylene gas (released when calcium } \\
\text { carbide comes in contact with water) are used. }\end{array}$ \\
\hline 3. & $\begin{array}{l}\text { Organic pulses: } \\
\text { Moong, Chana, Toor, Masoor, } \\
\text { Urad, Arhar, Kidney Beans, etc. }\end{array}$ & $\begin{array}{l}\text { Techniques like crop rotations, mulches and } \\
\text { mechanical control like practices are used to grow } \\
\text { organic pulses. Organically grown pulses are sweeter } \\
\text { and enriched with high nutritional elements }\end{array}$ \\
\hline 4. & $\begin{array}{l}\text { Fruit juices: } \\
\text { Coconut water, Orange juice, Apple } \\
\text { juice, Pineapple juice, Aloe Vera } \\
\text { juice, Gooseberry juice, Amla juice }\end{array}$ & -- \\
\hline 5. & $\begin{array}{l}\text { Food grains: } \\
\text { Wheat, Millet, Corn, Maize, and } \\
\text { Rice. }\end{array}$ & $\begin{array}{l}\text { Instead of using Synthetic Nitrogen Fertilizers and } \\
\text { persistent Herbicides and Pesticides, mulches, } \\
\text { organic fertilizers, and Cow dung compost are used. }\end{array}$ \\
\hline 6. & $\begin{array}{l}\text { Milk: } \\
\text { Organic milk }\end{array}$ & $\begin{array}{l}\text { Milk obtained from cows are not treated with growth } \\
\text { hormones and antibiotics, }\end{array}$ \\
\hline 7. & $\begin{array}{l}\text { Meat: } \\
\text { Organic meat }\end{array}$ & Organic Meat is enriched with Omega- 3 and CLA \\
\hline 8. & $\begin{array}{l}\text { Tea : } \\
\text { Organic tea }\end{array}$ & More flavored tea leaves with high nutritional value \\
\hline 9. & $\begin{array}{l}\text { Eggs: } \\
\text { Organic eggs }\end{array}$ & \\
\hline 10. & $\begin{array}{l}\text { Beverages: } \\
\text { Coffee, Tulsi Green Tea, Jaljeera, } \\
\text { Aam panna, Nimbupani, Sugarcan } \\
\text { juice, toddy and kokum juice. }\end{array}$ & -- \\
\hline
\end{tabular}

Fig1. Category of Organic foods

Source: http://www.iuemag.com/g17/fh/ten-best-organicfood-products-in-india

In this paper, presently available literature has been analyzed using keywords such as 'organic food products', 'consumer perception and organic food products ', 'consumer attitudes and organic food products' 'sustainable products', 'consumer buying behavior and sustainable food products' etc. which have been searched over internet to get relevant abstracts of research papers or full research papers based on the topic. In order to broaden the timeline of the survey, the same and/or similar keywords has been utilized for performing a further search through the web-based GoogleScholarTM tool, Mendeley software and Research Gate engine. Thus, the resulting list of reference papers attempts to covers the last fifteen years period.

This section presents the conceptual framework as to how different factors affect the attitude of the consumer to buy the organic food product. As it can be seen from the figure, beliefs, perceptions and purchasing behavior of consumers are the mediators which influences the attitude of the consumers. This attitude is then build up to action to purchase the product.

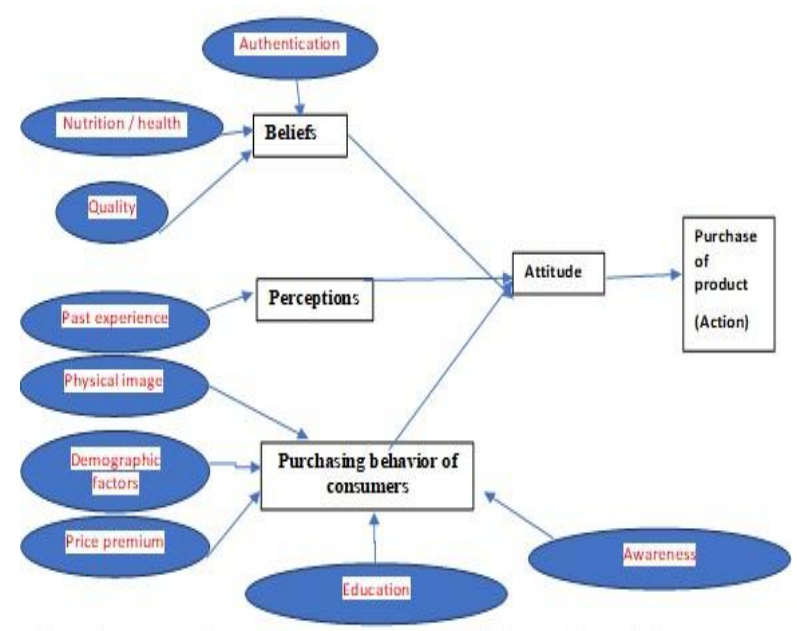

Fig 2. Conceptual Framework on studying the behavior of consumers towards the purchase of Organic foods

\section{HYPOTHESIS TESTING}

This study is aimed at testing the following hypotheses:

\section{1 $H_{A}$ : Attitude towards organic food product will} positively influence its purchase

Among the many determinants of sustainable product choices, attitude is found to be as one of the most effective factors[6]. Gracia\&Magistris [7] founded that attitude towards organic food was one of the major predictor of purchasing these food types. There are researches available in which consumer attitudes and motivation to purchase organic food products, consumer perception and beliefs towards purchase of organic food products were discussed at large [6], [8], [9] , [10],[11], [12],[13],[14],[15].

The mediator sub hypotheses for this hypothesis are as follows: 4.1.1 $H_{B}$ : belief towards organic food product will have a positive influence on the attitude of consumers 4.1.2 $H_{P}$ : Perception towards organic food product will have positive influence of the attitude of the consumers

\subsection{3 $H_{P B}$ : Purchasing behavior of consumers} positively influences the attitude of the consumers The sub-hypotheses corresponding to each mediator hypothesis have been described below:

\subsection{1 $H_{B}$ : belief towards organic food product will have a positive influence on the attitude of consumers}

Hypotheses on this sub criteria are as follows :

$>\mathrm{H}_{\mathrm{a}}$ : Authentication towards organic labels will have a positive influence on the belief of consumers and in turn affects their willingness to pay

Awareness of organic labels can increase the probability of paying a premium by consumers. In contrast, consumers experiencing more difficulty in identifying organic foods labels will likely show a drop in their intention to purchase organic foods [10]. 
> $\mathrm{H}_{\mathrm{k}}$ : Knowledge about the health benefits/ nutritious value of organic food products have positive influence over the purchase behavior of consumer towards organic food products

In order to describe the emerging consumer groups, factors such as nutritional values, naturalness or health values of food products, as well as sociodemographic attributes were used. It was found that variables such as food and safety concerns, health consciousness were the driving variables to influence the consumer intention to buy organic food products [6], [16],[17],[18], [19]).

$>\mathrm{H}_{\mathrm{q}}$ : Perceive quality of the organic food product will have positive influence on consumer's intention or belief to purchase the organic food product

Perceive quality is another factor to be vital on consumer's purchase behaviour. Roitner-Schobesbergeret al. [11] also confirmed that shoppers would like to see more variety from where they can select products to purchase. The two quality aspects of food product viz. the taste and visual attractiveness are factors related to the frequency of buying organic fruits and vegetables ([17],[20],[21]).

\subsection{2 $H_{P}$ : Perception towards organic food product will have positive influence of the attitude of the consumers \\ Hypothesis on this mediator hypothesis is as follows:}

$>\mathrm{H}_{\mathrm{PE}}$ : Past experience about the organic food product will positively influence the perception towards it

Verbeke and Vackier [22] opined how past experience influences the fish consumption through the theory of planned behavior. In a study at South Korea, Bo [23] reported that past experience have a positively significant influence on consumers' purchase intention of organic food.

\subsection{3 $H_{P B}$ : Purchasing behavior of consumers} positively influences the attitude of the consumers Hypotheses on this mediator hypothesis are as follows :

$>\mathrm{H}_{\mathrm{PP}}$ : Physical packaging and presentation of organic food product have positive influence over its purchase

Mann [24] argued that the physical image and presentation of organic produce are good enough to hasten consumption and social acceptance.

$\mathrm{H}_{\mathrm{PS}}$ : Price premium has positive influence on the purchasing behavior of the consumers

The price premium (generally 50-70 \% more than conventional food) is a determining factor for a lot of shoppers ([25]).

$>\mathrm{H}_{\mathrm{E}}$ :Education and knowledge about the organic food product will have positive influence on the purchasing behavior of the consumers

Clearly, education significantly influences the level of awareness for organic products ([26]). Further, the study by Pieniaket al.[27] investigates the association between consumers' subjective knowledge, objective knowledge and general attitudes towards organic food and organic vegetables consumption.

$>\mathrm{H}_{\mathrm{A}}$ : Awareness about organic farming and agriculture and organic labels have positiveinfluence on the purchasing behavior of the consumers

Sakagami [28] measures the consumer preferences regarding organic labelling. Zhifeng and Schroeder [29] investigates in detail the effect of label information on consumer willingness to pay for food attributes. Linder et al. [30] investigates how organic labelling influences food valuation and choice.

$>\mathrm{H}_{\mathrm{D}}$ : Demographic factors such as age, gender, income will have positive influence over the purchasing behavior of product

Bartels and Rienders[31] opined that gender has a profound effect on organic buying behaviour, and contrary to the findings of Ghorbani and Hamraz [17], it was identified by them that men in U.K. spent more money on organic products than women without offering an explanation. Bartels and Rienders [31] also revealed that age and income were significant positive predictors of consumer behavior. Additionally, it was confirmed that the younger generation spent more money for organic food than did older people.

\section{DESIGN OF QUESTIONNAIRE AND HYPOTHESIS TESTING}

In order to test the abovementioned hypotheses the research is conducted in two stages. In the first stage, a focus group or targeted consumers have been recognized. Initially the research is exploratory in nature. Based on the literature exploration, various factors influencing the consumer's experience are determined , a questionnaire has been designed to collect the responses on various aspects of buying behaviour, consumption patterns, economics of consumers. Thereafter the questionnaire is circulated amongst the respondents of age groups 18-60 years who are contacted via online survey. The questionnaire consists of closed ended questions. Questionnaire consists of different section. The first section of the questionnaire includes background questions which includes questions on demographic variables such as age, income, gender, education level, monthly income of family, occupation, family size and number of working persons in the family. Second section of the questionnaire includes the awareness questions. Third section of the questionnaire includes questions to test the customer's beliefs, knowledge, attitude and perceptions of consumers towards organic food products. Fourth section of questionnaire includes questions to test the purchasing behavior of the consumers towards organic food products.

\section{MANAGERIAL IMPLICATIONS}

The study can have profound implications for managers from various perspectives such as logistics, infrastructure and management.

\section{- Logistic perspective}

This perspective takes in to account packaging, labelling, hygiene factors, distribution and channel maintenance etc. Also, logistic cost minimization which includes storage costs, temperature maintenance cost for different category of organic food products can be considered as part of price premium on organic food products.

\section{- Infrastructure perspective}


This perspective will take into account the end-to-end logistics right from allotting suitable land to farmers to transportation systems and them storage and further distribution to wholesalers and retailers. Similarly, linking infrastructure to information technology will smoothen the supply chain of organic food product.

\section{- Management perspective}

Also, from management point of view quality inspection and control will incur additional costs which need to be taken care while deciding on the pricing of organic food product. Keeping in consideration the price sensitivity factor of consumers, continuous consumer feedback and suggestions needs to be incorporated to attract new customers as well to gain existing customer loyalty. Production manager should keep in mind the demographic factors as well as education and awareness level of targeted consumers while deciding on the price of the product and also while designing the product's physical image. Market testing is suggested before developing the product so as to gain deeper insights relating to the demand and viability of organic food products in the targeted market. This is highly demandable as lot of investment goes into the R\&D of the product and moving blindly will lead to serious losses for producer. Further pre testing of targeted market is suggested before launching the new product so as to gain acceptance of consumers towards the product.

\section{CONCLUSIONS AND POSSIBLE EXTENSIONS}

The research paper presents a conceptual framework of the various factors which affects the consumer behaviour and perceptions towards organic food products purchase. Present research may also include aspects such as recyclable (environment friendly) packaging. Other sustainable products which can be included could be petrochemicals, composts products etc. Environment friendly e-vehicle can also be used for logistics of sustainable products.

\section{ACKNOWLEDGEMENTS}

Authors extends their thanks to the anonymous reviewers of their manuscript.

\section{REFERENCES}

[1] Chouichom, S. and Yamao, M. 2010. 'Comparing opinions and attitudes of organic and non-organic farmers towards organic rice farming system in northeastern Thailand', Journal of Organic Systems, 5(1), pp. 25-34.

[2] William, Y., Kumju, H., Seonaidh, M. and Caroline, J.O. 2010. 'Sustainable Consumption: Green Consumer Behaviour when Purchasing Products', 18, pp. 20-31.

[3] Snyder, C., \& Spaner, D. 2010. 'The Sustainability of Organic Grain Production on the Canadian Prairies. A Review', Sustainability, 2, pp. 1016-1034.

[4] Hughner, R. S., McDonagh, P., Prothero, A., Schultz, C. J. and Stanton, J. 2007. 'Who are organic food consumers? A compilation and review of why people purchase organic food', Journal of Consumer Behavior, 6, pp. 94-110.

[5] Voon , J.P. , Sing , N.K. and Agarwal , A. 2011. 'Determinants of Willingness to Purchase Organic Food: An Exploratory Study Using Structural Equation Modeling', The International Food and Agribusiness Management Review, 14(2), pp.103-120.
[6] Hosseinpour, M., Mohamed, Z., Rezai, G., Shamsudin, M. N., \&Abdlatif, I. 2015. 'How Go Green Campaign Effects on Malaysia Intention towards Green Behaviour', Journal of Applied Sciences, 15(6), pp.929-933.

[7] Gracia, A., \&Magistris, T. de. 2007. 'Organic food product purchase behaviour: a pilot study for urban consumers in the South of Italy', Spanish Journal of Agricultural Research, 5(4), p.439-451.

[8] Mc Eachern, M. and Mc Clean, P. 2002. 'Organic purchasing motivations and attitudes: Are they ethical?', International Journal of Consumer Studies, Vol.26, pp. 85-92.

[9] Makatouni, A. 2002. 'What motivates consumers to buy organic food in the UK?', British Food Journal,Vol.104, pp. 345-352.

[10] Chen, M. F. 2007. 'Consumers attitudes and purchase intentions in relation to organic foods in Taiwan: Moderating effects of food-related personality traits', Food Quality and Preference, Vol.18, pp.1008-1021.

[11] Roitner-Schobesberger, B., Darnhofer, I., Somsook, S. and Vogl, C. R. 2008. 'Consumer perception of organic foods in Bangkok, Thailand', Food Policy, Vol.33, pp. 112-121.

[12] Salleh, M. M., Ali, S. M., Harun, E. H., Jalil, M. A., \&Shaharudin, M. R. 2010. 'Consumer's perception and purchase intentions towards organic food products: Exploring attitude among academicians', Canadian Social Science, Vol.6(6), pp.119-129.

[13] Stolz, H., Stolze, M., Hamm, U., Janssen, M., \& Ruto, E. 2010. 'Consumer attitudes towards organic versus conventional food with specific quality attributes', NJASWageningen Journal of Life Sciences, Vol.58, pp. 67-72.

[14] Grankvist, G. and Biel, A. 2001. 'The importance of beliefs and purchase criteria in the choice of eco-labeled food products', Journal of Environmental Psychology, Vol.21, pp. 405-410.

[15] Urban , J. , Zverinoya , I. and Scansy, M. 2012. 'What motivates Czech consumers to buy organic food ? effects of label information on consumer willingness to pay for food attributes', SociologickýČasopis / Czech Sociological Review ,48(3), pp. 509-536.

[16] Jan, V., Nguib, K. S. and Anand, A. 2011. 'Determinants of Willingness to Purchase Organic Food: An Exploratory Study Using Structural Equation Modeling', International Food and Agribusiness Management Review, 14(2).

[17] Ghorbani, M., \& Hamraz, S. 2009. 'A study on factors affecting on consumer's potential willingness to pay for organic products in Iran (a case study)', Trends in Agriculture Economics, 2, pp.10-16.

[18] Napolitano, F., Braghieri, A., Piasentier, E., Favotto, S., Naspetti, S. and Zanoli, R. 2010. 'Effect of information about organic production on beef liking and consumer willingness to pay', Food Quality and Preference, 21, pp. 207-212.

[19] Giovanni, P., Alessandro, M. P. and Gianluigil, G. 2012. 'Determinants of Regular and Occasional Consumers' Intentions to Buy Organic Food', Journal of consumer affairs, 46(1), pp. 157-169, Wiley. 
[20] Marshall, D. W. and Bell, R. 2004. 'Relating the food involvement scale to demographic variables, food choice and other constructs', Food Quality and Preference, 15, p. 971-979.

[21] Mergenthaler, M., Weinberger, K. and Qaim, M. 2009. 'Consumer Valuation of Food Quality and Food Safety Attributes in Vietnam', Review of Agricultural Economics, 31(2), pp. 266-283.

[22] Verbeke, W. and Vackier, I. 2005. 'Individual determinants of fish consumption: application of the theory of planned behavior', Appetite, 44, pp.67-82.

[23] Bo, S. W. 2009. 'Factor Influencing Consumers' Perceptions, Intention to Purchase and Realised Purchase Behaviour for Organic Food in South Korea', (Doctorate Dissertation, University of Surrey). Retrieved April 20, 2017 from http://epubs.surrey.ac.uk/2873/

[24] Mann (2003)

[25] Brown, C. and Sperow, M. 2005. 'Examining the cost of an all-organic diet', Journal of Food Distribution Research, Vol.36, pp. 20-26.

[26] Briz, T. and Ward, R. W. 2009. 'Consumer awareness of organic products in Spain: An application of multinomial logit models', Food Policy,.34, pp. 295-304.

[27] Pieniak, Z., Aertsen, J. and Verbeke, W. 2010. 'Subjective and objective knowledge as determinants of organic vegetable consumption', Food Quality and Preference, 21, pp. 581-588.

[28] Sakagami, M., Sato, M. and Ueta, K. 2006. 'Measuring consumer preferences regarding organic labeling and the JAS label in particular', New Zealand Journal of Agricultural Research, 49, pp.247-254.

[29] Zhifeng, G. and Schroeder, T.C. 2009. 'Effects of label information on consumer willingness-to-pay for food attributes', American Journal of Agricultural Economics , 91, pp. 795- 809.

[30] Linder, N. S., Uhl, G., Fliessbach, K., Trautner, P., Elger, C. E. and Weber, B. 2010. 'Organic labeling influences food valuation and choice', Neuro Image, 53, pp. 215220

[31] Bartels, J. and Rienders, M. 2010. 'Social identification, social representations, and consumer innovativeness in an organic food context: A cross-national comparison', Food Quality and Preference, 21, pp.347-352. 